\title{
Aging Alters the Rhythmic Expression of Vasoactive Intestinal Polypeptide mRNA But Not Arginine Vasopressin mRNA in the Suprachiasmatic Nuclei of Female Rats
}

\author{
Kristine Krajnak, Michael L. Kashon, Katherine L. Rosewell, and Phyllis M. Wise \\ Department of Physiology, Chandler Medical Center, University of Kentucky, Lexington, Kentucky 40536-0084
}

Our laboratory has shown that the ability of the suprachiasmatic nuclei (SCN) to regulate a number of rhythmic processes may be compromised by the time females reach middle age. Therefore, we examined the effects of aging on the rhythmic expression of two neuropeptides synthesized in the SCN, vasoactive intestinal polypeptide (VIP) and arginine vasopressin (AVP), using in situ hybridization. Because both VIP and AVP are outputs of the SCN, we hypothesized that age-related changes in rhythmicity are associated with alterations in the patterns of expression of these peptides. We found that VIP mRNA levels exhibited a $24 \mathrm{hr}$ rhythm in young females, but by the time animals were middle-aged, this rhythm was gone. The attenuation of rhythmicity was associated with a decline in the level of mRNA per cell and in the number of cells in the SCN producing detectable VIP mRNA. AVP mRNA also showed a robust $24 \mathrm{hr}$ rhythm in young females. However, in contrast to VIP, the AVP rhythm was not altered in the aging animals. The amount of mRNA per cell and the number of cells expressing AVP mRNA also was not affected with age. Based on these results we conclude that (1) various components of the SCN are differentially affected by aging; and (2) age-related changes in various rhythms may be attributable to changes in the ability of the SCN to transmit timing information to target sites. This may explain why the deterioration of various rhythmic processes occurs at different rates and at different times during the aging process.

Key words: rhythms; suprachiasmatic nuclei; aging; vasoactive intestinal polypeptide; arginine vasopressin; females
Virtually all organisms exhibit $24 \mathrm{hr}$ rhythms in numerous physiological and behavioral processes. In mammals, these rhythms are entrained to the light/dark (LD) cycle by a circadian pacemaker located in the suprachiasmatic nuclei (SCN) (Meijer and Rietveld, 1989). With age, many endogenous rhythms are blunted, and their entrainment to the LD cycle changes (Wise, 1984; Cohen and Wise, 1988; Weiland and Wise, 1989; Monk, 1991; Copinschi and Van Cauter, 1994; Li and Satinoff, 1995; Monk et al., 1995; Van Cauter et al., 1996; Wise et al., 1996). Evidence suggests that these disruptions may be attributable to alterations in the circadian pacemaker. First, some (Pittendrigh and Daan, 1974) but not all (Vaswanathan and Davis, 1995; Duffy and Davis, 1997) studies demonstrate that the period of activity rhythms (Ralph et al., 1990) shortens with age. Second, the ability of aged animals to shift their activity patterns in response to photic and nonphotic stimuli changes (Rosenberg et al., 1991; Penev et al., 1995; Zhang et al., 1996). Third, endogenous rhythmicity in spontaneous firing of SCN neurons in vitro is blunted (Satinoff et al., 1993). Some of these alterations can be reversed by implanting fetal SCN tissue into the third ventricle (Van Reeth et al., 1994; Vaswanathan and Davis, 1995; Cai et al., $1997 a, b)$ suggesting that these changes in the expression of circadian rhythms result in part from changes in SCN function.

\footnotetext{
Received Jan. 8, 1998; revised March 24, 1998; accepted March 31, 1998.

This work was supported by National Institutes of Health Grants AGO2224 to P.M.W., AGO5755 to K.K., and AGO5762 to M.L.K. We thank Susan Steman and Dr. Jacob P. Harney for technical assistance. We also thank Dr. R. H. Goodman (Vollum Institute) and Dr. T. Sherman (Georgetown University) for supplying us with cDNAs to VIP and AVP.

Correspondence should be addressed to Dr. Kristine Krajnak, Department of Physiology, MS508 Chandler Medical Center, University of Kentucky, Lexington, KY 40536-0084.

Copyright (C) 1998 Society for Neuroscience $\quad 0270-6474 / 98 / 184767-08 \$ 05.00 / 0$
}

Neurons in the SCN synthesize numerous neuropeptides (van den Pol and Tsujimoto, 1985) that may constitute output pathways to other brain regions. Few studies have examined the effects of aging on the rhythmic expression of these peptides. We assessed the effects of aging on the rhythmic gene expression of vasoactive intestinal polypeptide (VIP) and arginine vasopressin (AVP). VIP is synthesized primarily in the ventral SCN, whereas AVP is produced in a different population of neurons in the dorsomedial SCN (van den Pol and Tsujimoto, 1985; Watts and Swanson, 1987). Although these neuronal populations synapse with each other (Kaikoku et al., 1992), little is known about how they interact. Both VIP and AVP neurons relay circadian information to the basal forebrain and various hypothalamic and thalamic nuclei (Watts and Swanson, 1987). These projections regulate rhythms of gonadotropin-releasing hormone $(\mathrm{GnRH})$ release (Cheesman et al., 1977; Osland et al., 1977; van der Beek et al., 1995; Harney et al., 1996; Palm et al., 1997) and glucocorticoid release (Scarbrough et al., 1996; Buijs, 1997) and activity (Pickard and Turek, 1983; Sollars and Pickard, 1995; Murphy et al., 1997). Thus, age-related alterations in VIP or AVP expression may affect the transmission of rhythmic information from the SCN to target sites. We also chose to examine the effects of aging on these two peptides because aging differentially affects their expression in other brain regions. In the cortex, there is a dramatic decline in VIP cell number with aging (Andreose et al., 1994; Cha et al., 1995, 1997; Huh et al., 1997). In contrast, AVP synthesized in the paraventricular nuclei (PVN) and supraoptic nuclei of the hypothalamus is unaltered or mildly depressed by aging (Dobie et al., 1991; Sladek and Olschowka, 1994), whereas AVP synthesized in the bed nucleus of the stria terminalis is reduced (Lucassen et al., 1998). Thus, the effects of aging on these two neuropeptides may be region-dependent. 
We assessed the effects of age on the rhythmicity of these neuropeptides in females because cyclic reproduction, which is intimately linked to the circadian clock (Turek and Van Cauter, 1988; Hastings, 1991), exhibits profound changes by the time animals are middle-aged (Wise et al., 1996). In young females, the timing of the proestrous (Legan and Karsch, 1975) and estrogeninduced (Legan et al., 1975) surge of luteinizing hormone (LH) is tightly coupled to the LD cycle. However, in middle-aged animals, the LH surge is delayed, and the amplitude of the surge is attenuated (Wise, 1982; Nass et al., 1984). We have demonstrated that the rhythmic expression of multiple neurotransmitters and receptors (Weiland and Wise, 1986, 1989; Cohen and Wise, 1988; Lloyd et al., 1991) is blunted by middle age, suggesting that fundamental changes in the SCN may cause a deterioration in the ability to maintain regular reproductive cycles. In the present experiment, we assessed VIP and AVP mRNA levels in the SCN of young, middle-aged, and old females. If aging involves a change in all the essential elements (i.e., inputs, oscillators, and outputs) of the SCN, the pattern of expression of both these peptides would be affected. On the other hand, if only some of the components of the clock are affected with age, we might observe differential effects on VIP compared with AVP.

\section{MATERIALS AND METHODS}

Animals. Young, regularly cycling (2-4 months; six to eight animals per time point), middle-aged, irregularly cycling (10-12 months; six animals per time point), and old, persistent diestrous (18-20 months; six animals per time point) females were housed in a $14 / 10 \mathrm{hr}$ LD cycle (lights on at $0400 \mathrm{hr}$ ) with food and water available ad libitum. Vaginal cytology was checked daily for at least 2 weeks to determine the reproductive state of animals. All animals were ovariectomized under Metofane (methoxyflurane) inhalant anesthesia. One week later, SILASTIC capsules containing $17-\beta$-estradiol $(180 \mu \mathrm{g} / \mathrm{ml}$ in sesame oil; young, $20 \mathrm{~mm}$ capsule; middle-aged and old, $30 \mathrm{~mm}$ capsule) were implanted subcutaneously to clamp plasma estradiol at equivalent and physiological levels in all experimental groups (Wise, 1984). This is critical because ovarian steroids modulate the period of circadian activity (Morin et al., 1977; Takahashi and Menaker 1980; Albers et al., 1981) and the precise pattern of expression of VIP mRNA (Krajnak et al., 1997). Animals were killed at the following times after estrogen treatment: $2400 \mathrm{hr}$ (day 1) and 0300, 0800, 1200, 1600, 2000, and $2300 \mathrm{hr}$ (day 2).

VIP and AVP in situ hybridization. In situ hybridization methods were the same as previously described (Wise et al., 1992; Krajnak et al., 1997). Briefly, brains were removed, rapidly frozen, and stored at $-70^{\circ} \mathrm{C}$ until sectioned. Frozen coronal sections $(12 \mu \mathrm{m})$ through the basal forebrain and hypothalamus were sliced, thaw-mounted onto slides, and stored at $-80^{\circ} \mathrm{C}$ until processed for in situ hybridization (ISH). Slides containing sections from the middle to midcaudal SCN (three slides or six sections per animal) were chosen for VIP ISH, and alternate slides (two slides or four sections per animal) were chosen for AVP ISH. The riboprobe for VIP was generated using a 500 bp human cDNA directed against exons 3-6 of the VIP-peptide histidine isoleucine gene (from Dr. R. H. Goodman, Vollum Institute). The riboprobe for AVP was generated using a $241 \mathrm{bp}$ cDNA directed against exon $\mathrm{C}$ of the rat AVP gene (provided by Dr. T. Sherman, Georgetown University). Both riboprobes were transcribed using $50 \mu \mathrm{M}$ total UTP. Because each cDNA contains a different percentage of UTP, we used different amounts of ${ }^{35} \mathrm{~S}$-UTP to produce comparable incorporation of the radiolabeled nucleotide (VIP, $12.5 \mu \mathrm{M}{ }^{35} \mathrm{~S}$-UTP and $37.5 \mu \mathrm{M}$ unlabeled UTP and SP6 polymerase; AVP, $37.5 \mu \mathrm{M}{ }^{35} \mathrm{~S}$-UTP and $12.5 \mu \mathrm{M}$ unlabeled UTP and SP6 polymerase). Slides were thawed, fixed with $4 \%$ paraformaldehyde, and dehydrated using a series of increasing concentrations of ethanol. Hybridization buffer $(50 \mu \mathrm{l})$ containing $400 \mathrm{ng} / \mathrm{ml}$ labeled VIP cRNA or $200 \mathrm{ng} / \mathrm{ml}$ AVP cRNA was applied to each slide. In preliminary studies, saturation curves were generated and revealed that these concentrations of cRNA produced maximal labeling without significantly increasing background. Slides were incubated in humid chambers at $55^{\circ} \mathrm{C}$ for $18 \mathrm{hr}$, washed under stringent conditions, dehydrated with ethanol, coated with Kodak NTB2 emulsion (Eastman Kodak, Rochester, NY; diluted 1:1 with distilled water), and stored at $4^{\circ} \mathrm{C}$. Slides processed for AVP were developed $5 \mathrm{~d}$

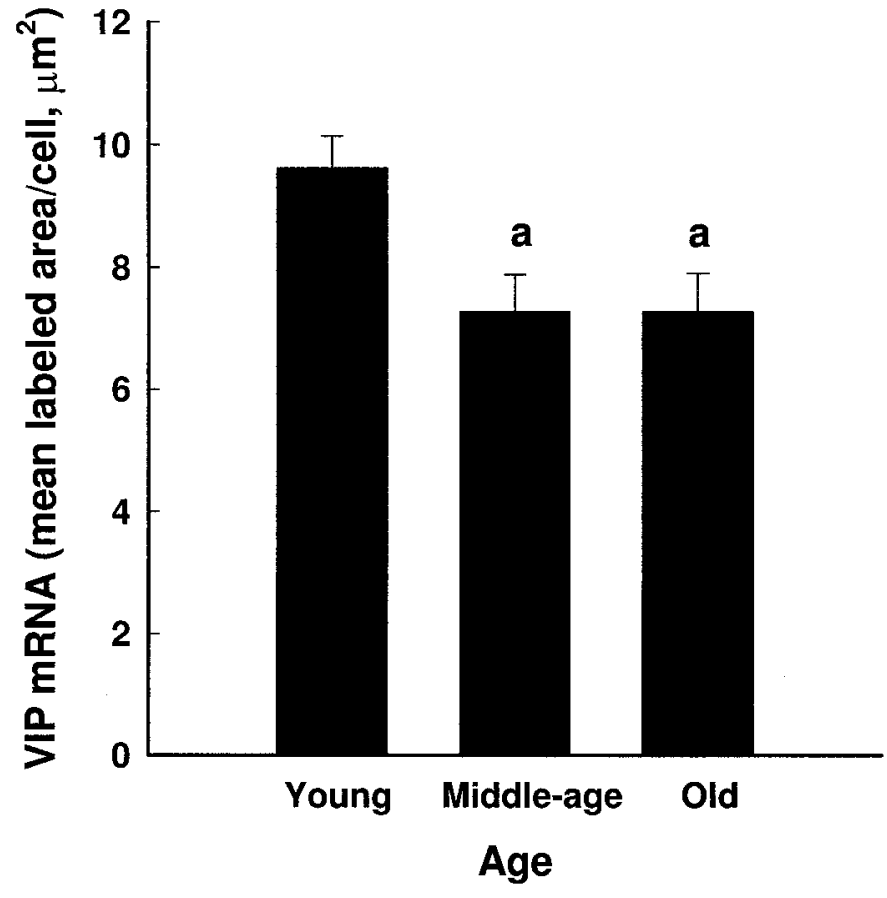

Figure 1. Overall levels of VIP mRNA per cell in young, middle-aged, and old females (mean \pm SEM). The 3 (age) $\times 7$ (time of day) ANOVA revealed a significant effect of age $\left(F_{(2,101)}=5.99 ; p<0.004\right)$ on mRNA levels per cell. VIP gene expression was significantly lower in middle-aged and old females compared with young $(p<0.05)$.

after emulsion coating, and slides processed for VIP were developed $10 \mathrm{~d}$ after emulsion coating. All slides were counterstained with $0.05 \%$ toluidine blue so that individual cell bodies could be identified.

All slides were examined for the presence of labeling in the SCN. If the SCN from an individual animal was damaged, mRNA levels were not quantified in those slides. Therefore, in some animals, AVP was not quantified, and in others, VIP was not quantified. Gene expression was quantified using the Bioquant OS/2 image analysis system. Slides from a number of animals were examined, and a single threshold for determining grains versus background was set. The perimeter of an individual cell was outlined, and both the area of the cell and portion covered by grains (i.e., above threshold) were quantified. Lighting and contrast levels were standardized before taking measurements to assure that all slides were assessed under the same conditions. Background was assessed by taking measurements over unlabeled cells outside the area of interest. Cells having a value five times higher than background were considered labeled.

Analyses. To determine whether aging altered VIP or AVP gene expression per cell in the SCN or the number of cells labeled for these peptides, 3 (age) $\times 7$ (time of day) ANOVAs were performed. Planned comparisons using one-way ANOVAs examining the effects of time on gene expression in each age group were performed to determine whether gene expression was rhythmic. Post hoc comparisons were made using Newman-Kuels tests. Differences were considered significant if $p<0.05$.

\section{RESULTS}

\section{VIP gene expression}

Two-way ANOVA revealed a main effect of age on VIP mRNA per cell (Fig. 1) $\left(F_{(2,101)}=5.99 ; p<0.004\right)$ but no effect of time $\left(F_{(6,101)}=0.81 ; p=0.57\right)$ and no interaction $\left(F_{(12,101)}=1.50 ; p=\right.$ $0.14)$. Further analyses showed that VIP mRNA levels per cell were lower in middle-aged and old than in young females $(p<$ $0.05)$. VIP-expressing cells in all animals were seen predominantly in the ventrolateral SCN. However, as animals aged, there appeared to be a loss of VIP gene expression in the most medially located neurons (Fig. 2). The two-way ANOVA on the number of $\mathrm{VIP}$-expressing cells in the SCN revealed a main effect of age 

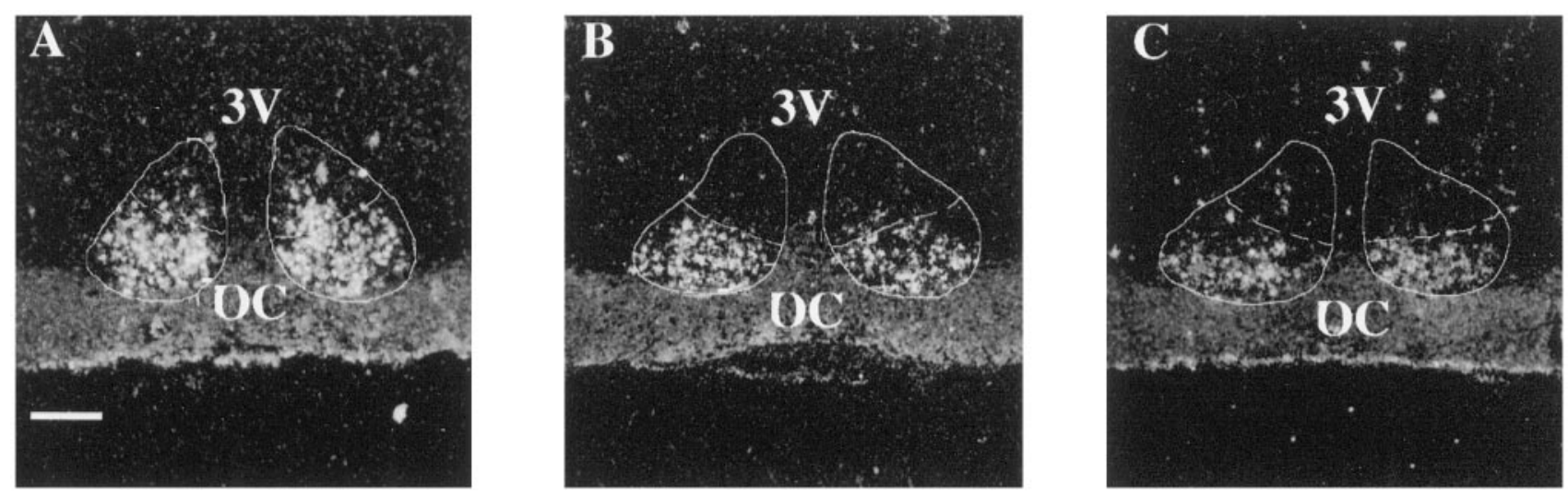

Figure 2. This photomicrograph shows VIP labeling in the SCN of young $(A)$, middle-aged $(B)$, and old $(C)$ females at 1200 hr. VIP labeling was seen predominantly in the ventrolateral portion of the SCN in all animals. However, as animals age, there appears to be a decrease in the number of VIP-expressing cells in the medial portion of the nucleus. $3 \mathrm{~V}$, Third ventricle; $O C$, optic chiasm. Scale bar, $25 \mu \mathrm{m}$.

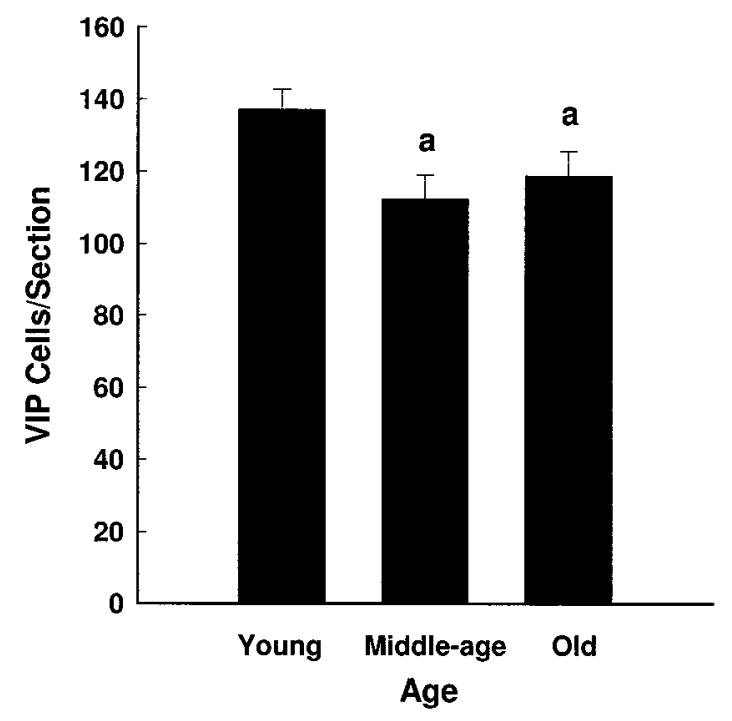

Figure 3. VIP-expressing cells per section (mean \pm SEM) in young, middle-aged, and old females. The two-way ANOVA analyzing the effects of age and time of day on the number of VIP-expressing cells revealed a main effect of age $\left(F_{(2,101)}=4.53 ; p<0.02\right)$, with the number of VIP-expressing cells per section being higher in young than in middleaged or old females $(p<0.05)$.

$\left(F_{(2,101)}=4.53 ; p<0.02\right)$ but no effect of time $\left(F_{(6,101)}=1.27\right.$; $p=0.28)$ and no interaction $\left(F_{(12,101)}=0.80 ; p=0.65\right)$. Further analyses showed that the number of cells expressing VIP mRNA was lower in the middle-aged and old females than in the young females (Fig. 3).

To determine whether there was a rhythm in VIP gene expression in young, middle-aged, and old females, we performed planned comparisons using one-way ANOVAs on VIP mRNA levels at each age. In young females, VIP gene expression was rhythmic $\left(F_{(6,43)}=3.03 ; p<0.02\right)$, with mRNA levels being lower at 0300, 0800, and $2000 \mathrm{hr}$ than at the other time points $(p<0.05$; Fig. 4). By the time animals reached middle age, a rhythm in VIP gene expression was no longer detectable (middle age, $F_{(6,31)}=$ $0.61 ; p=0.72$; old, $\left.F_{(6,27)}=0.93, p=0.49\right)$.

\section{AVP gene expression}

Two-way ANOVA revealed a main effect of time on the amount of AVP mRNA per cell (Fig. 5) $\left(F_{(6,108)}=18.73 ; p<0.001\right)$ but

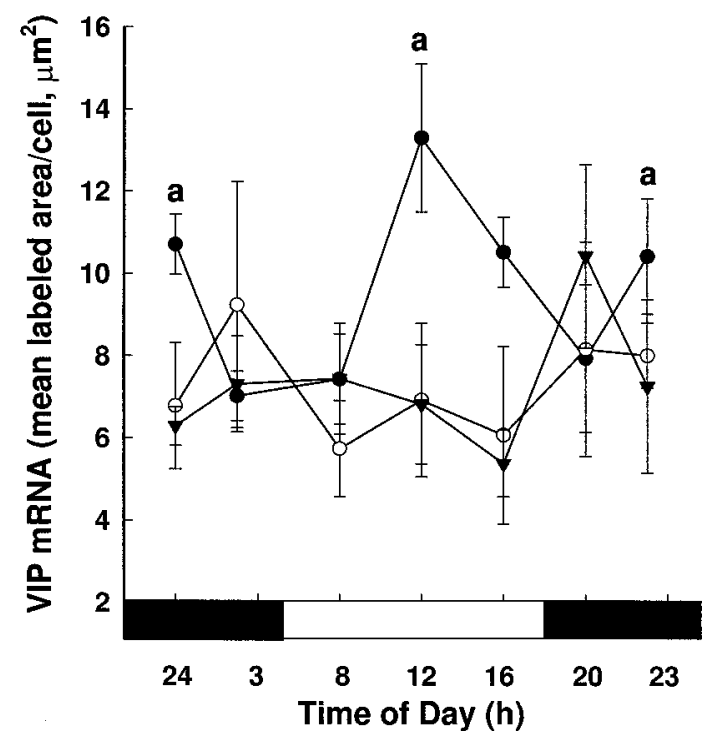

Figure 4. VIP mRNA levels per cell (mean \pm SEM) over time in young $(\mathbf{O})$, middle-aged $(O)$, and old $(\boldsymbol{\nabla})$ females. One-way ANOVA revealed that VIP mRNA was rhythmic in young females $\left(F_{(6,43)}=3.03 ; p<0.02\right)$, with VIP gene expression being higher at 2400, 1200, and $2300 \mathrm{hr}$ than at other times of day $\left({ }^{*} p<0.05\right)$. VIP mRNA levels did not significantly fluctuate over the day in middle-aged or old females. The black bar under the $x$-axis represents the dark phase of the cycle, and the white bar represents the light phase.

no effect of age $\left(F_{(2,108)}=0.64 ; p=0.53\right)$ and no interaction $\left(F_{(12,108)}=0.55 ; p=0.87\right)$. Post hoc analyses examining the effect of time revealed a prominent rhythm in AVP gene expression in all groups. AVP mRNA levels were low between 2400 and $0300 \mathrm{hr}$ and exhibited significant increases at each time point from 0800 to $1600 \mathrm{hr}(p<0.05)$. After $1600 \mathrm{hr}$, AVP mRNA returned to baseline levels, showing a significant decrease at both 2000 and $2300 \mathrm{hr}(p<0.05)$. Planned comparisons using one-way ANOVAs to determine whether AVP mRNA expression was rhythmic were consistent with the two-way ANOVA; AVP gene expression was rhythmic in all age groups (young, $F_{(6,54)}=10.17 ; p<0.001$; middle-aged, $\left(F_{(6,28)}=6.99 ; p<0.001 ;\right.$ and old, $F_{(6,26)}=3.81$; $p<0.008)$, with AVP mRNA levels being highest at $1600 \mathrm{hr}$ and lowest at $0300 \mathrm{hr}(p<0.05$ in all age groups).

AVP gene expression was seen predominantly in the dorsome- 


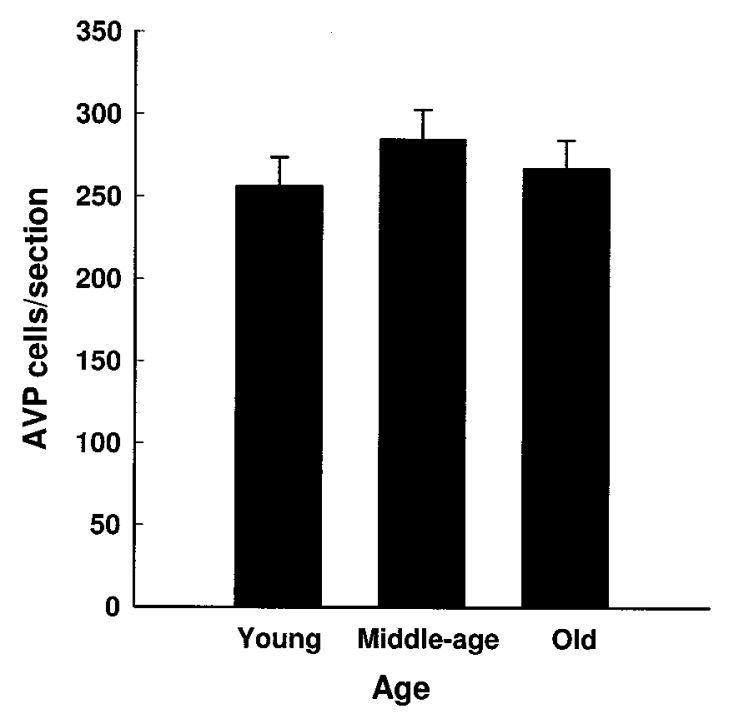

Figure 5. AVP-expressing cells per section (mean $\pm \mathrm{SEM}$ ) in young, middle-aged, and old females. Aging did not alter the number of AVPexpressing cells in the SCN of females $\left(F_{(2,108)}=0.928 ; p=0.399\right)$.

dial portion of the SCN in all animals examined (Fig. 6). The two-way ANOVA on the number of cells expressing AVP mRNA per section revealed a main effect of time on cell number $\left(F_{(6,108)}\right.$ $=11.19 ; p<0.001)$ but no effect of age $\left(F_{(2,108)}=0.93 ; p=0.40\right)$ and no interaction $\left(F_{(12,108)}=1.43 ; p=0.16\right)$. The effect of time on cell number was similar to that seen on AVP mRNA levels (Fig. 7). The number of cells expressing AVP mRNA was low between 2400 and $0800 \mathrm{hr}$ and increased to reach peak levels by $1600 \mathrm{hr}(p<0.05)$. The number of AVP-expressing cells then began to fall and decreased significantly by $2300 \mathrm{hr}(p<0.05)$. Aging did not alter this pattern, nor did it affect the number of cells expressing AVP mRNA (Fig. 8).

\section{DISCUSSION}

Previous studies demonstrate that aging alters the expression of numerous physiological and behavioral rhythms that are driven by the SCN. This raises the possibility that age-related deterioration of the pacemaker itself may underlie the changes in rhythmicity of these diverse physiological endpoints. Therefore, the purpose of this study was to examine the effects of aging on two major peptides synthesized within the SCN, VIP and AVP, to determine whether the rhythmic expression of their mRNAs was altered.

We focused our attention on these two neuropeptides because (1) they are critical neuropeptides synthesized rhythmically in the SCN (Inouye et al., 1993); this rhythmic expression dictates the ability of the SCN to interpret environmental cues (Kiss et al., 1984; Bosler and Beaudet, 1985; Hisano et al., 1988; Ibata et al., 1989) and drive multiple outputs (Osland et al., 1977; Sodersten et al., 1983; Sollars and Pickard, 1995; van der Beek et al., 1995; Harney et al., 1996; Scarbrough et al., 1996; Palm et al., 1997); and (2) these peptides also modulate the timing of GnRH secretion (van der Beek et al., 1995; Huhman and van der Beek, 1996; Palm et al., 1997), which is critical to cyclic reproduction in females. Our study was performed in females because reproductive success in this sex is intimately tied to the SCN and begins to display overt signs of senescence by middle age (Wise et al., 1996, 1997). Our results clearly demonstrate a selective age-related alteration in VIP gene expression in the absence of any change in AVP gene expression.

The rhythm of VIP mRNA was not detectable by the time animals reached middle age. In young females, VIP mRNA showed a peak at $\sim 1200 \mathrm{hr}$ and a smaller rise during the midevening. This finding is consistent with our previous work, which showed that mRNA levels in females are high during the day, and that this daytime rise is coincident with the timing of the $\mathrm{LH}$ surge in young females (Krajnak et al., 1997). Other studies also indicate that if VIP activity in young females is blocked in the hour just before the surge with either antisense oligonucleotides to VIP (Harney et al., 1996) or VIP antibodies (van der Beek et al., 1995), the timing of the surge is delayed, and the amplitude is attenuated. Thus, the loss of the daytime peak of VIP mRNA in middle-aged animals may be responsible for the delay in the timing and attenuation in the amplitude of the LH surge.

The rise in VIP mRNA during the middle of the dark phase (2300-2400 hr) was also attenuated in aging animals. In young males, VIP mRNA levels and peptide concentrations in the SCN are high at night and decline after lights on (Albers et al., 1990; Inouye et al., 1993; Krajnak et al., 1997). Thus, it has been hypothesized that these light-induced changes in VIP may provide environmental LD information to the pacemaking cells in the SCN (Albers et al., 1991). However, it is unclear whether the rise in VIP mRNA at 2300-2400 hr that we observe in young females serves the same function. If it does, this signal is absent by the time females reach middle age. Because VIP neurons receive input from all major afferents to the SCN (Kiss et al., 1984; Bosler and Beaudet, 1985; Hisano et al., 1988; Ibata et al., 1989), this decline in mRNA could be in part responsible for the decreased ability of both photic and nonphotic stimuli to phase shift rhythms in aged animals (Rosenberg et al., 1991; Penev et al., 1995; Zhang et al., 1996). Similar changes may also occur in males. Kawakami et al. (1997) found a slight decrease in VIP mRNA at night in old males (22-24 months) when they monitored gene expression at one time during the light phase and one time during the dark phase. The number of VIP-immunolabeled cells within the SCN during the light phase of the cycle may also decline in very old (33-34 months) males (Chee et al., 1988).

Several possible mechanisms may underlie the age-related decline in the rhythm of VIP mRNA in the SCN. First, both photic input from the retina (Ibata et al., 1989) and serotonin (5-HT) input from the raphe (Kiss et al., 1984; Bosler and Beaudet, 1985) regulate the rhythm of VIP gene expression and peptide concentrations. Eliminating photic input to the SCN of adult males by placing animals in persistent darkness (Inouye et al., 1993) or by enucleation (Okamoto et al., 1990) results in a loss of VIP rhythmicity and an overall increase in VIP expression. Thus, it is possible that alterations in the retinal input to the SCN lead to the loss of rhythmic VIP gene expression by middle age. In aged animals, light-induced fos expression is attenuated in the SCN (Sutin et al., 1993; Zhang et al., 1996; Cai et al., 1997), which is concomitant with a decline in the magnitude of light-induced phase shifts (Zhang et al., 1996). However, subjecting aged animals to brighter light pulses partially reverses these dampened responses (Zhang et al., 1996), suggesting that there may be age-related affects on the ability of the retina to perceive and transmit photic information. However, retinal degenerative mice, whose retina show signs of aging relatively early, do not exhibit any decline in the ability to respond to phase-shifting light pulses (Garcia-Fernandez et al., 1995). Together, these observations suggest that the retinal signal may be maintained with aging, but 

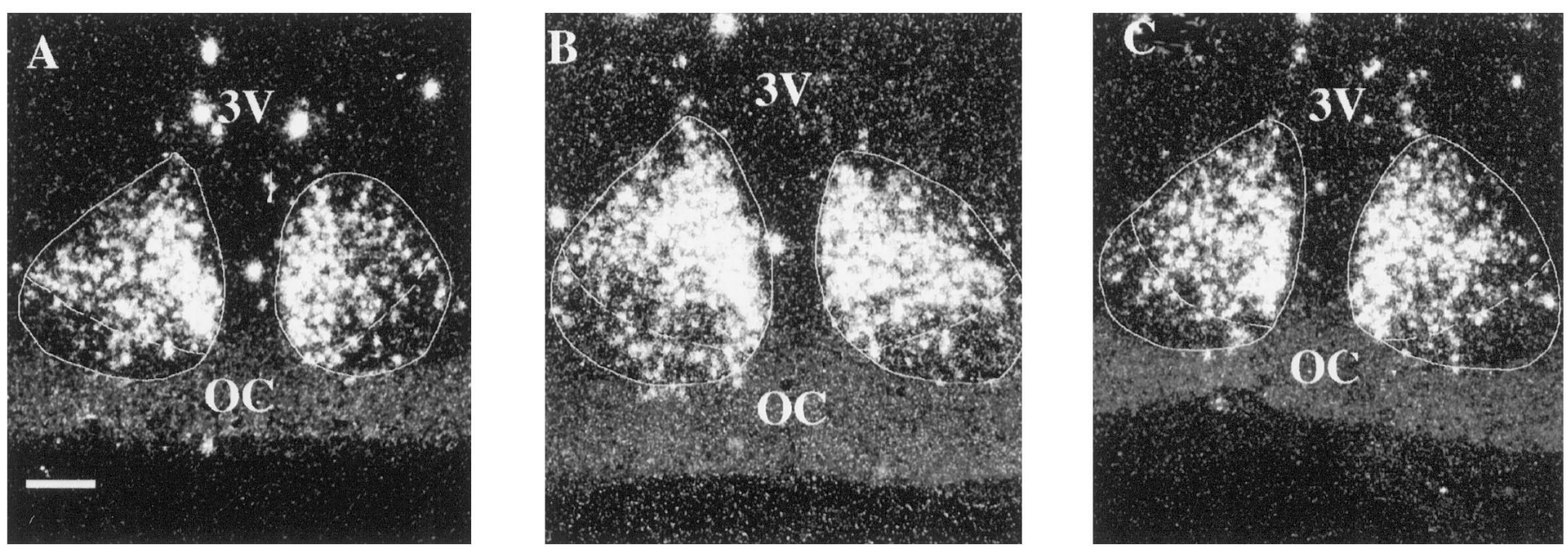

Figure 6. These photomicrographs show AVP mRNA labeling in the SCN of young $(A)$, middle-aged $(B)$, and old $(C)$ females at 1200 hr. AVP expression was seen primarily within the dorsomedial portion of the SCN in all groups of animals. $3 V$, Third ventricle; $O C$, optic chiasm. Scale bar, $25 \mu \mathrm{m}$.

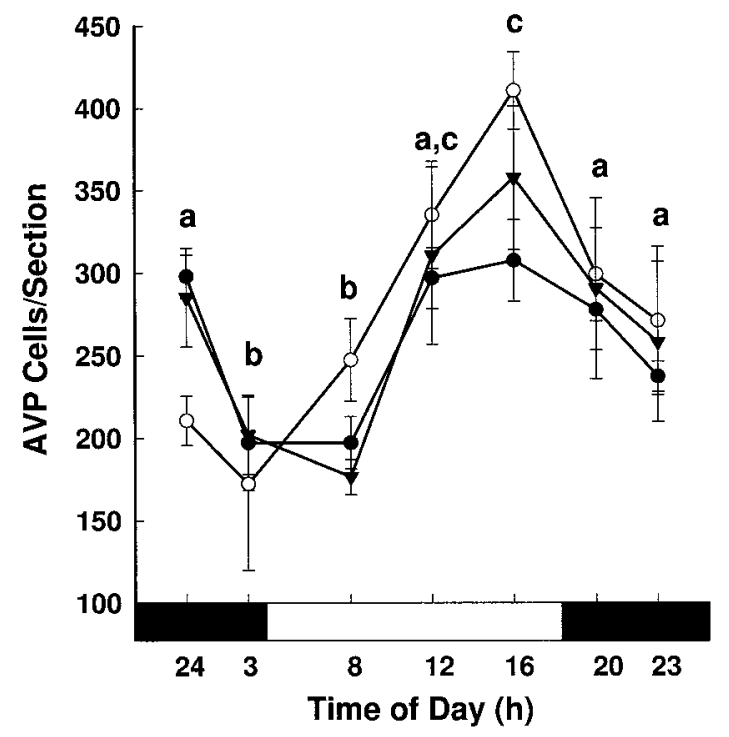

Figure 7. AVP-expressing cells per section (mean \pm SEM) over time in young $(\bullet)$, middle-aged $(\bigcirc)$, and old females $(\boldsymbol{\nabla})$. The two-way ANOVA examining the effects of age and time of day on AVP cell number revealed a significant effect of time $\left(F_{(6,108)}=11.19 ; p<0.001\right)$, with the number of AVP-expressing cells gradually increasing between 0300 and $1600 \mathrm{hr}$ and then declining to baseline levels by $2300 \mathrm{hr}$ (different letters are significantly different from each other; $p<0.05$ ). The black bar under the $x$-axis represents the dark phase of the cycle, and the white bar represents the light phase.

that the ability of the SCN to receive this signal may be altered. Because retinal input appears to synapse directly onto VIPproducing neurons (Ibata et al., 1989), and light induces fos expression within VIP neurons (Daikoku et al., 1992; Speh and Moore, 1996; Rominj et al., 1996), it is possible that age-related changes in VIP alter the transmission of photic information to other pacemaking target cells within the SCN or efferent targets in other regions of the brain. However, the phenotype of neurons showing reduced fos activation in aged animals needs to be determined before we know exactly which outputs of the SCN might be altered.

VIP concentrations (Kawakami et al., 1985) and gene expres-

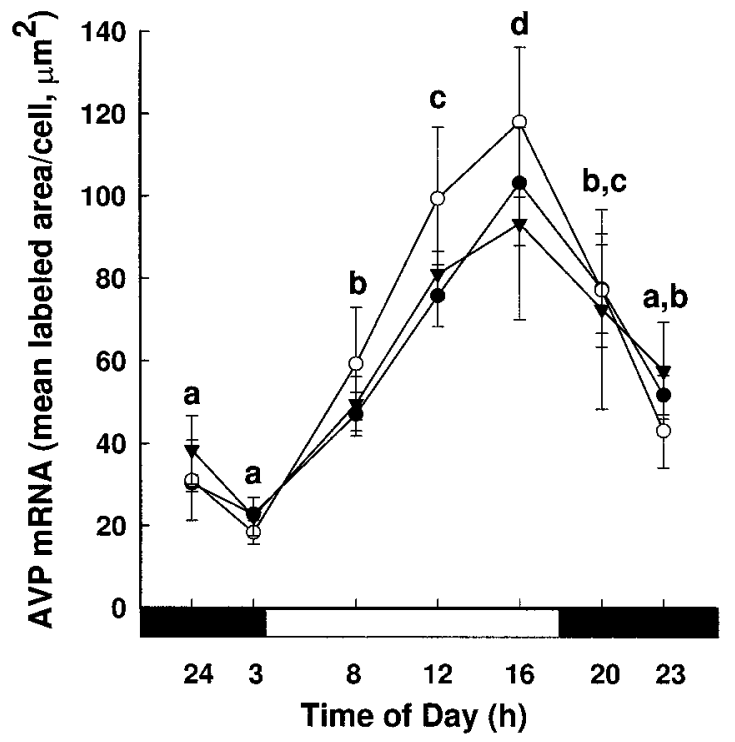

Figure 8. AVP mRNA levels per cell (mean \pm SEM) over time in young $(\mathbf{O})$, middle-aged $(\bigcirc)$, and old females $(\boldsymbol{\nabla})$. The 3 (age) $\times 7$ (time of day) ANOVA revealed a main effect of time on AVP mRNA levels $\left(F_{(6,108)}=\right.$ 18.73; $p<0.001$ ), with AVP mRNA levels increasing between 0300 and $1600 \mathrm{hr}$ and then declining to baseline levels by $2300 \mathrm{hr}$ (different letters are significantly different from each other; $p<0.05$ ). The black bar under the $x$-axis represents the dark phase of the cycle, and the white bar represents the light phase.

sion (Okamura et al., 1995) are also modulated by 5-HT. 5-HT terminals from the raphe synapse directly on VIP-producing neurons in the SCN (Kiss et al., 1984), and lesioning this input results in a loss of VIP and a dramatic decline in VIP expression within the SCN rhythmicity (Kawakami et al., 1985, 1994; Okamura et al., 1995). Studies have shown that the rhythm in 5-HT turnover is altered by the time females reach middle age (Cohen and Wise, 1988) and that 5-HT projections to the $\mathrm{SCN}$ are diminished (Van Luijtelaar et al., 1989). The ability of 5-HT to cause phase shifts in activity rhythms is also reduced in aged animals (Penev et al., 1995). Thus, the age-related changes in 5-HT input to the SCN may have dramatic effects on both the rhythmic expression of VIP and the amount of VIP expressed. 
The most surprising finding of this study is that the AVP rhythm remains completely intact in the same animals in which the rhythmic expression of VIP was absent. The rhythm in gene expression, the number of cells expressing AVP, and the amount of AVP mRNA per cell were unaltered, even in the oldest group of females. These results are consistent with data collected from aged males showing that the number of AVP-immunopositive neurons in the SCN was not altered in males 16-18 months of age (Roozendaal et al., 1987; Lucassen et al., 1995). These findings are remarkable in that most entrained rhythms that have been examined show age-related alterations in rhythmic expression (Wise et al., 1987, 1997; Satinoff et al., 1993; Sutin et al., 1993; Zhang et al., 1996; Cai et al., 1997).

AVP projections from the SCN serve as an output, carrying timing information to a number of target areas, including regions involved in generation of the LH surge (Watson and Langub, 1996) and generation of the rhythm in corticosteroid release (Buijs, 1997). Our findings showing that neither the rhythmic expression of AVP nor the amount of AVP expressed per cell changes during aging helps explain the maintenance of the daily rhythm in corticosterone despite the absence of a rhythm in corticotropin-releasing hormone (CRH) mRNA in the PVN of aged animals (Cai and Wise, 1996). Buijs (1997) has reported a multisynaptic pathway between SCN AVP neurons and the adrenal that bypasses PVN CRH. In addition, our data lead us to conclude that changes in the timing or amplitude of the LH surge seen in middle-aged animals are unlikely attributable to changes in the AVP signal. However, it is possible that changes in the ability of target sites to recognize the AVP signal occur in aging females.

The rhythm in AVP synthesis and release is endogenous and driven by the SCN (Gillette and Reppert, 1987; Inouye et al., 1993). Thus, these rhythms are maintained in constant conditions. However, under LD conditions, the AVP rhythm is also tightly coupled to the LD cycle (Burbach et al., 1988; Inouye et al., 1993). Our findings show that this rhythm remains tightly coupled to the LD cycle throughout aging. However, other entrained rhythms regulated by the SCN and synchronized to the LD cycle, such as glucose utilization (Wise et al., 1987), Fos induction by the LD cycle (Sutin et al., 1993; Zhang et al., 1996; Cai et al., 1997), and activity rhythms (Satinoff et al., 1993), lose their tight coupling to the LD cycle during aging. In fact, when temperature, activity, and drinking rhythms are monitored in the same elderly animal, a deterioration in the entrainment and amplitude of one rhythm is not necessarily correlated with a deterioration in the other rhythms (Satinoff et al., 1993). Together these studies support the hypothesis that age-related changes in the expression of rhythmic processes are the result of the uncoupling of various oscillators within the SCN and not necessarily attributable to complete deterioration of the ability of the SCN to generate rhythms.

In summary, our results show that the rhythmic expression of VIP in the SCN is undetectable by the time females reach middle age, but AVP expression in these same animals is unaltered. Based on these findings, we suggest that the differential effects of age on these two outputs may explain why certain rhythms are altered with age, whereas others remain intact. Future studies should concentrate on changes in the inputs to the SCN to determine how age-related alterations in these inputs may affect the ability of the SCN to entrain rhythms to the environment. Other studies, concentrating on how individual oscillators are coupled and how this coupling is altered by aging, will also help us determine why some rhythms are more resistant to the effect of aging than others.

\section{REFERENCES}

Albers HE, Gerall AA, Axelson JF (1981) Effect of reproductive state on circadian periodicity of rat. Physiol Behav 26:21-25.

Albers HE, Stopa EG, Zoeller RT, Kauer JS, King JC, Fink JS, Mobtaker H, Wolfe H (1990) Day-night variation in prepro-vasoactive intestinal peptide/peptide histidine isoleucine mRNA within the rat suprachiasmatic nucleus. Mol Brain Res 7:85-89.

Albers HE, Liou S-Y, Stopa EG, Zoeller RT (1991) Interaction of colocalized neuropeptides: functional significance in the circadian timing system. J Neurosci 11:846-851.

Andreose JS, Fumagalli G, Clementi F (1994) On the effect of aging on the distribution of vasoactive intestinal polypeptide and calcitonin gene-related peptide in the rat brain. Neurosci Lett 171:167-171.

Bosler O, Beaudet A (1985) VIP neurons as prime synaptic targets for serotonin afferents in rat suprachiasmatic nucleus: a combined autoradiographic and immunocytochemical study. J Neurocytol 14:749-763.

Buijs RM (1997) The anatomical basis for the expression of circadian rhythms: the efferent projections of the suprachiasmatic nucleus. In: Progress in brain research (Buijs RM, Kalsbeek A, Romijn HJ, Pennartz CMA, Mirmiran M, eds), pp 231-240. New York: Elsevier Science.

Burbach JPH, Liu B, Voorhuis TAM, VanTol HHM (1988) Diurnal variation in vasopressin and oxytocin messenger RNAs in hypothalamic nuclei of the rat. Mol Brain Res 4:157-160.

Cai A, Wise PM (1996) Age-related changes in the diurnal rhythm of $\mathrm{CRH}$ gene expression in the paraventricular nuclei. Am J Physiol 270:E238-E243.

Cai A, Lehman MN, Lloyd JM, Wise PM (1997a) Transplantation of fetal suprachiasmatic nuclei into middle-aged rats restores diurnal fos expression in the host. Am J Physiol 272:R422-R428.

Cai A, Scarbrough K, Hinkle DA, Wise PM (1997b) Fetal grafts containing suprachiasmatic nuclei restore the diurnal rhythm of CRH and POMC mRNA in aging rats. Am J Physiol 273:R1764-R1770.

Cha CI, Lee EY, Lee YI, Baik SH (1995) Age related change in the vasoactive intestinal polypeptide-immunoreactive neurons in the cerebral cortex of aged rats. Neurosci Lett 197:45-48.

Cha CI, Lee YI, Lee EY, Park KH, Baik SH (1997) Age-related changes in VIP, NPY and somatostatin-immunoreactive neurons in the cerebral cortex of aged rats. Brain Res 753:235-244.

Chee CA, Roozendaal B, Swaab DF, Goudsmit E, Mirmiran M (1988) Vasoactive intestinal peptide neuron changes in the senile rat suprachiasmatic nucleus. Neurobiol Aging 9:307-312.

Cheesman DW, Osland RB, Forsham PH (1977) Suppression of the preovulatory surge of luteinizing hormone and subsequent ovulation in the rat by arginine vasotocin. Endocrinology 101:1194-1202.

Cohen IR, Wise PM (1988) Age-related changes in the diurnal rhythm of serotonin turnover in microdissected brain areas of estradiol-treated ovariectomized rats. Endocrinology 122:2626-2633.

Copinschi G, Van Cauter E (1994) Pituitary hormone secretion in aging: roles of circadian rhythmicity and sleep. Eur J Endocrinol 131:441-442.

Daikoku S, Yokote R, Kawano H (1992) Light stimulation of the hypothalamic neuroendocrine system. Arch Histol Cytol 55:67-76.

Dobie DJ, Miller MA, Urban JH, Raskind MA, Dorsa DM (1991) Age-related decline of vasopressin mRNA in the bed nucleus of the stria terminalis. Neurobiol Aging 12:419-423.

Duffy JF, Davis FC (1997) Free-running circadian period in aging female Syrian hamsters. Soc Neurosci Abstr 23:1326.

Garcia-Fernandez JM, Jimenez AJ, Foster RG (1995) The persistence of cone photoreceptors within the dorsal retina of aged retinally degenerate mice $(r d / r d)$ : implications for circadian organization. Neurosci Lett 187:33-36.

Gillette MU, Reppert SM (1987) The hypothalamic suprachiasmatic nuclei: circadian patterns of vasopressin secretion and neuronal activity in vitro. Brain Res Bull 19:135-139.

Harney JP, Scarbrough K, Rosewell KL, Wise PM (1996) In vivo antisense antagonism of vasoactive intestinal peptide in the suprachiasmatic nucleus causes aging-like changes in the estradiol-induced LH and prolactin surge. Endocrinology 137:3696-3701.

Hastings MH (1991) Neuroendocrine rhythms. Pharmacol Ther $50: 35-71$.

Hisano S, Chikamori-Aoyama M, Katoh S, Kagotani Y, Daikoku S, Chihara K (1988) Suprachiasmatic nucleus neurons immunoreactive 
for vasoactive intestinal polypeptide have synaptic contacts with axons immunoreactive for neuropeptide $\mathrm{Y}$ : an immunoelectron microscopic study in the rat. Neurosci Lett 88:145-150.

Huh Y, Kim C, Cho J, Lee W, Kim J, Ahn S (1997) Differential effects of aging on NADPH-diaphorase and VIP neurons in cerebral cortex of rats. NeuroReport 8:2991-2994.

Huhman KL, van der Beek EM (1996) Peptidergic innervation of gonadotropin releasing hormone $(\mathrm{GnRH})$ neurons in female Syrian hamsters. Soc Neurosci Abstr 22:1141.

Ibata Y, Yakahaski Y, Okamura H, Kawakami F, Terubayashi H, Kubo T, Yanaihara N (1989) Vasoactive intestinal peptide (VIP)-like immunoreactive neurons located in the rat suprachiasmatic nucleus receive a direct retinal projection. Neurosci Lett 97:1-5.

Inouye S-iT, Shinohara K, Tominaga K, Takeuchi J, Nagasaki H, Isobe Y, Fukuhara C, Otori Y, Yang J, Cagampang FRA, Yamazaki S, Tokumasu A (1993) Circadian rhythms in peptides and their precursor messenger RNAs in the suprachiasmatic nucleus. In: New functional aspects of the suprachiasmatic nucleus of the hypothalamus (Nakagawa H, Oomura Y, Nagai K eds), pp 219-233. John Libbey.

Kaikoku S, Hisano S, Kagotani Y (1992) Neuronal associations in the rat suprachiasmatic nucleus demonstrated by immunoelectron microscopy. J Comp Neurol 325:559-571.

Kawakami F, Okamura H, Fukui K, Yanaihara C, Yanaihara N, Nakajima T, Ibata Y (1985) The influence of serotonergic inputs on peptide neurons in the rats suprachiasmatic nucleus: an immunocytochemical study. Neurosci Lett 61:273-277.

Kawakami F, Okamura H, Inatomi T, Tamada Y, Nakajima T, Ibata Y (1994) Serotonin depletion by p-chlorophenylalanine decreases VIP mRNA in the suprachiasmatic nucleus. Neurosci Lett 174:81-84.

Kawakami F, Okamura H, Tamada Y, Maebayashi Y, Fukui K, Ibata Y (1997) Loss of day-night differences in VIP mRNA levels in the suprachiasmatic nucleus of aged rats. Neurosci Lett 222:99-102.

Kiss J, Leranth C, Halasz B (1984) Serotinergic endings on VIP-neurons in the suprachiasmatic nucleus and on ACTH-neurons in the arcuate nucleus of the rat hypothalamus. A combination of high resolution autoradiography and electron microscopic immunocytochemistry. Neurosci Lett 44:119-124.

Krajnak K, Rosewell KL, Wise PM (1997) The diurnal rhythm of vasoactive intestinal polypeptide (VIP) gene expression in the suprachiasmatic nuclei (SCN) is different in male and female rats. Soc Neurosci Abstr 22:.

Legan SJ, Karsch FJ (1975) A daily signal for the LH surge in the rat. Endocrinology 96:57-62.

Legan SJ, Coon GA, Karsch FJ (1975) Role of estrogen as initiator of daily LH surges in the ovariectomized rat. Endocrinology 96:50-56.

Li H, Satinoff E (1995) Changes in circadian rhythms of body temperature and sleep in old rats. Am Physiol Soc R208-R214.

Lloyd JM, Scarbrough K, Weiland NG, Wise PM (1991) Age-related changes in proopiomelanocortin (POMC) gene expression in the periarcuate region of ovariectomized rats. Endocrinology 129:1896-1902.

Lucassen PJ, Hofman MA, Swaab DF (1995) Increased light intensity prevents the age related loss of vasopressin-expressing neurons in the rat suprachiasmatic nucleus. Brain Res 693:261-266.

Lucassen PJ, van Heerikhuize JJ, Guldenaar SEF, Pool CW, Hofman MA, Swaab DF (1998) Unchanged amounts of vasopressin mRNA in the supraoptic and paraventricular nucleus during aging and in Alzheimer's disease. J Neuroendocrinol 9:297-305.

Meijer JH, Rietveld WJ (1989) Neurophysiology of the suprachiasmatic circadian pacemaker in rodents. Physiol Rev 69:671-707.

Monk TH (1991) Sleep and circadian rhythms. Exp Gerontol 26:233-243.

Monk TH, Buysse DJ, Reynolds CF, III, Kupfer DJ, Houck PR (1995) Circadian temperature rhythms of older people. Exp Gerontol 30:455-474.

Morin LP, Fitzgerald KM, Zucker I (1977) Estradiol shortens the period of hamster circadian rhythms. Science 15:305-307.

Murphy HM, Wideman CH, Nadzam GR (1997) Vasopressin antagonists and circadian rhythms. Soc Neurosci Abstr 23:313.

Nass TE, Lapolt PS, Judd HL, Lu JKH (1984) Alterations in ovarian steroid and gonadotrophin secretion preceding the cessation of regular oestrous cycles in ageing female rats. J Endocrinol 100:43-50.

Okamoto S, Okamura H, Takahashi Y, Akagi Y, Yanaihara N, Ibata Y (1990) Contrary effect of eye enucleation on VIP-immunoreactive neurons in the suprachiasmatic nucleus and the superior colliculus of the rat. Neurosci Lett 112:137-142.
Okamura H, Kawakami F, Tamada Y, Geffard M, Nishiwaki T, Ibata Y, Inouye S-iT (1995) Circadian change of VIP mRNA in the rat suprachiasmatic nucleus following p-chlorophenylalanine (PCPA) treatment in constant darkness. Mol Brain Res 29:358-364.

Osland RB, Cheesman DW, Forsham PH (1977) Studies on the mechanism of the suppression of the preovulatory surge of luteinizing hormone in the rat by arginine vasotocin. Endocrinology 101:1203-1209.

Palm IF, Kalsbeek A, van der Beek EM, Hermes MLHJ, Weigant VM, Buijs RM (1997) Role of vasopressin in the medial preoptic area in the estradiol-induced luteinizing hormone and prolactin surge. Soc Neurosci Abstr 23:1245.

Penev PD, Zee PC, Wallen EP, Turek FW (1995) Aging alters the phase-resetting properties of a serotonin agonist on hamster circadian rhythmicity. Am J Physiol 37:R293-R298.

Pickard GE, Turek FW (1983) The hypothalamic paraventricular nucleus mediates the photoperiodic control of reproduction but not the effects of light on the circadian rhythm of activity. Neurosci Lett 43:67-72.

Pittendrigh CS, Daan S (1974) Circadian oscillations in rodents: a systematic increase of their frequency with age. Science 186:548-550.

Ralph MR, Foster RG, Davis FC, Menaker M (1990) Transplanted suprachiasmatic nucleus determines circadian period. Science 247:975-978.

Rominj HJ, Sluiter AA, Pool CW, Wortel J, Buijs RM (1996) Differences in colocalization between Fos and PHI, GRP, VIP and VP in neurons of the rat suprachiasmatic nucleus after a light stimulus during the phase delay versus the phase advance period of the night. J Comp Neurol 372:1-8.

Roozendaal B, Van Gool WA, Swaab DF, Hoogendijk JE, Mirmiran M (1987) Changes in vasopressin cells of the rat suprachiasmatic nucleus with aging. Brain Res 409:259-264.

Rosenberg RS, Zee PC, Turek FW (1991) Phase response curves to light in young and old hamsters. Am J Physiol 261:R491-R495.

Satinoff E, Li H, Tcheng TK, Liu C, McArthur AJ, Medanic M, Gillette MW (1993) Do the suprachiasmatic nuclei oscillate in old rats as they do in young ones? Am J Physiol 265:R1216-R1222.

Scarbrough K, Harney JP, Rosewell KL, Wise PM (1996) Acute effects of antisense antagonism of a single peptide neurotransmitter in the circadian clock. Am J Physiol 270:R283-R288.

Sladek CD, Olschowka JA (1994) Dehydration induces Fos, but not increased vasopressin mRNA in the supraoptic nucleus of aged rats. Brain Res 652:207-215.

Sodersten P, Henning M, Melin P, Ludin S (1983) Vasopressin alters female sexual behaviour by acting on the brain independently of alterations in blood pressure. Nature 301:608-610.

Sollars PJ, Pickard GE (1995) Vasoactive intestinal peptide efferent projections of the suprachiasmatic nucleus in anterior hypothalamic transplants: correlation with functional restoration of circadian behavior. Exp Neurol 136:1-11.

Speh JC, Moore RY (1996) Phase dependent differential distribution and co-localization of light-induced c-fos expression within VIP and/or GRP suprachiasmatic nucleus (SCN) neurons. Soc Neurosci Abstr 22:2053

Sutin EL, Dement WC, Heller HC, Kilduff TS (1993) Light-induced gene expression in the suprachiasmatic nucleus of young and aging rats. Neurobiol Aging 14:441-446.

Takahashi JS, Menaker M (1980) Interaction of estradiol and progesterone: effects on circadian locomotor rhythm of female golden hamsters. Am J Physiol 239:R497-R504.

Turek FW, Van Cauter E (1988) Rhythms in reproduction. In: The physiology of reproduction (Knobil E, Neill J, et al. eds), pp 1789-1830. New York: Raven.

Van Cauter E, Leproult R, Kupfer DJ (1996) Effects of gender and age on the levels and circadian rhythmicity of plasma cortisol. J Clin Endocrinol Metab 81:2468-2473.

van den Pol AN, Tsujimoto KL (1985) Neurotransmitters of the hypothalamic suprachiasmatic nucleus: immunocytochemical analysis of 25 neuronal antigens. Neuroscience 15:1049-1086.

van der Beek EM, Swarts JJM, Wiegant VM (1995) Central VIPantiserum injections alter the timing of an estrogen-induced LH surge. Soc Neurosci Abstr 21:742.8.

Van Luijtelaar MGPA, Steinbusch HWM, Tonnaer JADM (1989) Similarities between aberrant serotonergic fibers in the aged and 5,7-DHT denervated young adult rat brain. Exp Brain Res 78:81-89.

Van Reeth O, Zhang Y, Zee PC, Turek FW (1994) Grafting fetal 
suprachiasmatic nuclei in the hypothalamus of old hamsters restores responsiveness of the circadian clock to a phase shifting stimulus. Brain Res 643:338-342.

Vaswanathan N, Davis FC (1995) Suprachiasmatic nucleus grafts restore circadian function in aged hamsters. Brain Res 686:10-16.

Watson Jr RE, Langub MCJ (1996) Vasopressinergic synaptic input upon estrogen receptive neurons in the anterior preoptic region of the rat: suprachiasmatic nucleus origin? Soc Neurosci Abstr 18:113.

Watts AG, Swanson LW (1987) Efferent projections of the suprachiasmatic nucleus: II. Studies using retrograde transport of fluorescent dyes and simultaneous peptide immunohistochemistry in the rat. J Comp Neurol 258:230-252.

Weiland NG, Wise PM (1986) Effects of age on beta1- and beta2adrenergic receptors in the brain assessed by quantitative autoradiography. Brain Res 398:305-312.

Weiland NG, Wise PM (1989) Age-associated alterations in catecholaminergic concentrations, neuronal activity, and alpha-1 receptor densities in female rats. Neurobiol Aging 10:323-329.

Wise PM (1982) Alterations in proestrous LH, FSH, and prolactin surges in middle-aged rats. Proc Soc Exp Biol Med 169:348-354.
Wise PM (1984) Estradiol-induced daily luteinizing hormone and prolactin surges in young and middle-aged rats: correlations with agerelated changes in pituitary responsiveness and catecholamine turnover rates in microdissected brain areas. Endocrinology 115:801-809.

Wise PM, Walovitch RC, Cohen IR, Weiland NG, London ED (1987) Diurnal rhythmicity and hypothalamic deficits in glucose utilization in aged ovariectomized rats. J Neurosci 7:3469-3473.

Wise PM, Scarbrough K, Lloyd JM, Weiland NG, Larson GH, Chiu S (1992) Assessment of proopiomelanocortin gene expression in brain. Methods Neurosci 9:197-208.

Wise PM, Krajnak KM, Kashon ML (1996) Menopause: The aging of multiple pacemakers. Science 273:67-70.

Wise PM, Kashon ML, Krajnak KM, Rosewell KL, Cai A, Scarbrough K, Harney JP, McShane T, Lloyd J, Weiland NG (1997) Aging of the female reproductive system: a window into brain aging. Recent Prog Horm Res 52:279-305.

Zhang Y, Kornhauser JM, Zee PC, Mayo KE, Takahashi JS, Turek FW (1996) Effects of aging on light-induced phase-shifting of circadian behavioral rhythms, fos expression and CREB phosphorylation in the hamster suprachiasmatic nucleus. Neuroscience 70:951-961. 